\title{
Squamous cell carcinoma transformation in mature cystic teratoma of the ovary: A case report and review of literature
}

\author{
Namkha Dorji ${ }^{1}$, Sangay Tshering ${ }^{2}$, and Sonam Choden ${ }^{1}$ \\ ${ }^{1}$ Jigme Dorji Wangchuck National Referral Hospital \\ ${ }^{2}$ JDWNR Hospital
}

February 28, 2021

\begin{abstract}
Introduction: Malignant transformation in mature cystic teratoma of ovary is a rare complication. Case report: A 62-year-old woman was diagnosed with squamous cell carcinoma in a mature cystic teratoma of ovary. Conclusion: Malignant transformation should be suspected in elderly woman with large mature cystic teratoma of ovary with thickened wall.
\end{abstract}

Hosted file

Manuscript.pdf available at https://authorea.com/users/398683/articles/511308-squamouscell-carcinoma-transformation-in-mature-cystic-teratoma-of-the-ovary-a-case-report-andreview-of-literature 